УДК 378.147:616-051

DOI:

Ірина Зварич, доктор педагогічних наук, старший науковий співробітник, професор кафедри сучасних європейських мов Київського національного торговельно-економічного університету

\title{
ФОРМУВАННЯ ПРОФЕСІОНАЛІЗМУ МАЙБУТНІХ ЛІКАРІВ США
}

\section{(зарубіжний досвід)}

У статті здійснено аналіз формування професіоналізму майбутніх лікарів США, висвітлено підходи до формування майбутніх лікарів, зокрема проаналізовано підходи Джанелл Кокс які необхідні для педагога в прочесі викладання навчальних дисииплін, в тому числі і для підготовки майбутніх лікарів у вищих закладах освіти США, саме: толерантності, користування новітніми технологіями, креативності, командної гри, управління он-лайн технологіями, комунікативності, пошуку необхідних ресурсів в Інтернет мережі, безперервного навчання, відчуття темпу вивчення навчальної дисиипліни, адаптації до нових студентів та їхніх здібностей вивчати навчальний предмет.

Ключові слова: вищий заклад освіти; формування професіоналізму; вчителі та викладачі; підходи; навчальний предмет; сучасний розвиток; рівень якості; мотивація; уміння; комунікація.

Jim. 6.

Iryna Zvarych, Doctor of Sciences (Pedagogy), Senior Scientist Researcher, Professor of the Modern European Languages Department, Kyiv National University of Trade and Economics

\section{FORMING PROFESSIONALISM OF THE USA FUTURE PHYSICIANS} (foreign experience)

This article deals with the analyzing the forming professionalism of the USA future physicians, the approaches to the formation of future physicians are highlighted, in particular Janelle Cox's approaches are analyzed that are necessary for a lecturer in teaching disciplines, including for the preparation of the future physicians at the USA higher learning institutions, they are: tolerance, use of the latest technologies, creativity, team play, management of on-line technologies, communicative, search of the necessary resources on the Internet network, continuous training, feeling the subject study, adaptation to new the students and their ability to learn the necessary subject.

Following to the historicism principles, we briefly analyzed the facts that were the impetus for the formation of the USA students ' professionalism, in particular future physicians. From the point of history, the higher education in the United States has certain characteristics, in particular that the type of higher education in the United States has become a general higher education, which had a long formation way.

It is important to create the modern education in the context of certain requirements and capabilities with international standards and which are differ in the quality of knowledge, skills, and approaches to the process of mastering the disciplines, to the formation of specialists ' professionalism, in particular future physicians. To solve the problem of forming the students' professionalism successfully at higher learning institutions in Ukraine, it is necessary to study the foreign experiences and introduce the best one into the education process.

However, it's not necessary to borrow and copy the foreign experience. It is necessary to ensure the possibility of adapting this experience to the general cultural, socio-economic and institutional conditions of Ukraine, to diagnose the advantages and disadvantages of its implementation, and of course to take into account the traditions and achievements in the activities of domestic higher learning institutions that correspond to modern education development vectors in the world.

Keywords: higher learning institution; a formation of professionalism; teachers and lecturers; approaches; an educational subject; a modern development; a level of quality; motivation; skills; communication.

$\Pi$ остановка проблеми. Зростання новітніх технологій, демократизація та вектори гуманістичного прогресу в Україні призвели до еволюції особистостей студентів як головного важеля сучасного розвитку суспільства та держави. Основна роль у формуванні сучасної студентської особистості як професійної та громадянина належить до освіти. Освіта завжди відображає інтереси суспільства і виконує свої соціальні замовлення, формує суспільні вимоги до знань і перспективи прогресу; зміни під впливом тимчасових, соціальних, економічних та інших факторів вимагає якісного обслуговування освіти. Однією 3 вимог до якості освіти є адаптація студентів, зокрема майбутніх лікарів до своїх професійних обов'язків, безумовно для навчання, отримання знань $з$ навчальних предметів, професійних 
навичок та глибоких знань 3 дисциплін професійного спрямування.

Мета і завдання дослідження. Цю розвідку присвячено питанню вивчення досвіду формування професіоналізму майбутніх лікарів США, тому метою статті є вивчення підходів до формування професіоналізму Джанелл Кокс; висвітлення кожного підходу до формування професіоналізму студентів у вищих закладах освіти США. Отже завдання статті - висвітлити підходи до формування професіоналізму студентів, зокрема майбутніх лікарів США у вищих закладах освіти.

Аналіз основних досліджень та публікацій. Американський вчений Джанелл Кокс (Janelle Cox) надає перевагу висвітленню підходів до формування професіоналізму студентів США. Дженелл Кокс пропонує оволодіти новими важливими уміннями, навичками, які необхідні для формування професіоналізму студентів, зокрема майбутніх лікарів.

Виклад основного матеріалу. Реформування освіти в Україні, спрямованої на підвищення якості професійної освіти передбачає підготовку фахівців різного профілю. Запропонована реформа розширює можливості вищих закладів освіти щодо їхньої автономії, натомість широка автономія $\epsilon$ однією із складових сучасних систем вищої освіти, яка включає зовнішнє оцінювання рівня якості знань, що важливо для всіх студентів, особливо для тих, чия майбутня професія передбачає високий рівень відповідальності за безпеку та здоров'я людей, зокрема дітей. Саме до таких професій і належать - лікарі різного профілю, вчителі та викладачі, пілоти та архітектори. Їхня професія є регульована, яку часто називають регламентованою i яка вимагає набуття професійних навичок та вмінь, притаманних окремій професії, зокрема кваліфікацій зі знанням медичної освіти - лікарям. Відповідні сертифікати, ліцензії та інші документи засвідчують дотримання умов визначених законодавством певної країни і які надають право обіймати певну посаду.

Регульованими $\epsilon$ професії, пов'язані 3 збереженням життя, здоров'я людини, виникненням надзвичайних ситуацій техногенного чи природного характеру. Перелік таких професій визначає Кабінет Міністрів України [4].

У Законі України про систему професійних кваліфікацій зазначається, що регульована професія - це та, у межах якої доступ до професійної діяльності, присвоєння та підтвердження професійних кваліфікацій регулюються спеціальними нормативними актами.
В Україні існує 25 професійних груп, які поєднують близько 150 професій і понад 250 спеціалізацій до них, за якими здійснюється незалежне зовнішнє оцінювання (сертифікація) професійних кваліфікацій і які можна вважати регульованими [4]. До таких професій належать працівники охорони здоров'я, зокрема 138 спеціалізацій, архітектори, інженерипроектувальники (10 спеціалізацій), адвокати, нотаріуси, авіаційні фахівці, вчителі, працівники морського й водного транспорту, фахівці фінансового моніторингу та інші. В Україні нараховують близько 2 мільйони фахівців регульованих кваліфікацій, зокрема понад 1,2 млн. - представники сфери освіти, охорони здоров'я, морського та авіаційного транспорту, правоохоронної та суміжних з нею сфер діяльності [4].

Нині, питання щодо “регульованих професій” набирає актуальності, оскільки для забезпечення якісної підготовки фахівців за окремими професіями необхідно виконання обов'язкових вимог щодо рівня якості освіти, зокрема складання спеціальних екзаменів з відповідної професії, отримання ліцензій чи членства у асоціації професійного спрямування.

У вищих закладах медичної освіти США студенти здають екзамени на визначення рівня якості знань, зокрема із спеціалізації - IFOM. Це найбільш поширений екзамен з Міжнародних основ медицини (IFOM - International Foundations of Medicine). IFOM розробляється однією 3 найавторитетніших у світі атестаційних рад Національною радою медичних екзаменаторів Сполучених Штатів Америки (NBME - National Board of Medical Examiners). Тест містить 160 питань. На сьогодні тестування IFOM проводиться англійською мовою в комп'ютерному форматі упродовж чотирьох годин. За змістом тестові завдання IFOM охоплюють питання внугрішньої медицини, хірургії, педіатрії, психіатрії, акушерства та гінекології, які повинні знати студенти будь-якої країни світу, навчаючись на останньому курсі вищого медичного навчального закладу.

Структуру та зміст іспиту IFOM розроблено міжнародною експертною комісією, вона $є$ єдиною для усіх країн, які беруть участь у складанні екзамену IFOM. Студенти, які за результатами тестового іспиту IFOM отримають 602 бали або вище, отримають сертифікат NBME (The National Board of Medical Examiners) - про відповідність рівня професійної компетентності стандарту, що засвідчує рівень якості знань із відповідної професії лікаря. 
Міжнародний екзамен IFOM проходить у багатьох країнах світу. Вперше цей іспит був апробований у Франції як пілотний проект. Згодом, у 2007 р. IFOM проводився як моніторингове дослідження в Італії та Бельгії. Незабаром, у 2014 р. тест почали використовувати для порівняльного аналізу місцевих медичних іспитів в Австралії. Екзамен IFOM як випускний проводиться і для вступу на резидентуру в деяких країнах Близького Сходу та Латинської Америки на постійній основі. Спеціально розроблені клінічні завдання IFOM перевіряють знання з діагностики та лікування, базовані на сучасній доказовій медицині, найновіших методах і підходах до лікування. Для підготовки до такого іспиту університети, які готують медичних працівників певною мірою модернізують навчальні програми таким чином, щоб студентам дозволяли отримати високий рівень якості знань, зокрема сучасні знання 3 медичної освіти за професійним спрямуванням. Важливо відзначити, що йдеться не про знання детальних протоколів лікування хворих з інших країн, а про рівень якості науковообгрунтованих знань, умінь, навичок з медичної освіти, які є міжнародними за своєю природою, оскільки більшість проблем пацієнтів і лікарів однакові і в Свропі, і в Азії, і в Америці.

Екзамен IFOM складається із двох частин, зокрема запитання і знання із базових наук та клінічні об'єктивні знання (BSE - Basic Science and CSE - Clinical Sciences). Часто BSE виокремлюють як окремий іспит, що входить до складу IFOM. Саме тому багато 3 питань моделюються за допомогою іспиту USMLE, що традиційно включає низкуекзаменаційних питань, які в основному були орієнтовані на США, такі як охорона здоров'я населення. Міжнародні студенти-медики, як правило, мають нижчий бал у цих областях, враховуючи, що вони, зазвичай, не вивчали питанням, що відносяться до охорони здоров'я, орієнтованим на США.

Екзамен BSE відбувається у три етапи. Перший етап цього іспиту вважається самим складним, бо включає питання і завдання із анатомії, патанатомії, фізіології, біохімії, мікробіології, імунології, патології, фармакології, ембріології. Зазвичай завдання формують у вигляді клінічних захворювань, ситуацій із практичного досвіду. Мінімальна кількість балів, яка вважається прохідним балом, залежить від обраної спеціалізації. Зазвичай загальний прохідний бал - становить 175, але на спеціалізації стосовно хірургії необхідно набрати 250 із 384. Екзамен складається із 8 розділів і кожен має 48 різних запитань. Враховуючи кількість розділів із запитаннями, такий іспит триває 8-9 годин, оскільки на кожен розділ відводиться по 1 годині [6].

Другий етап - це теоретична частина (Clinical knowledge), яка складається із 8 розділів та 48 завдань теоретичного висвітлення знань 3 усіх предметів професійного спрямування. Третій етап - це практична частина (Clinical skills), яка включає оцінювання практичних навичків та вмінь, тому ця частина екзамену відбувається у формі стандартного обходу хворих у лікарні, зокрема спілкування із пацієнтами, вивчаються історії хвороби, встановлюється діагноз хвороби, назначається лікування хворим. Зазвичай хворих пацієнтів представляють актори.

Таким чином, іспит IFOM є корисним для студентів-медиків, оскільки вони можуть побачити, як їхній IFOM-бал трансформується на USMLE (The United States Medical Licensing Examination) - це триступеневий екзамен для медичного ліцензування в США, який є основою забезпечення здоров'я пацієнтів та надання безпечної та ефективної допомоги лікаря хворим. USMLE складається із USMLE перша базова частина (Basic Science), друга теоретична частина USMLE (Clinical Knowledge), третя практична частина USMLE (Clinical Skills).

До учасників екзаменаційних комісій USMLE входять вчені як лікарі, так і педагоги та клініцисти 3 усіх регіонів Сполучених Штатів. Слід зауважити, що всі акредитовані LCME медичні школи в Сполучених Штатах були представлені на тестових комісіях USMLE. Члени комітету з тестування USMLE представляють “національний медичний факультет” з медичних шкіл, державних медичних рад та клінічних практик у США.

Отже, бажано створити одну систему тестівекзаменів, прийняту в кожному штаті, щоб забезпечити ліцензування лікарів, які б пройшли ті ж самі стандарти оцінювання для визначенні професіоналізму, незалежно від того, в якій школі чи якій країні вони навчалися.

Розвиток професіоналізму студентів США, підвищення якості навчального процесу здійснюється за рахунок переосмислення традиційних форм і методів навчання, збільшення комплексу новітніх технологій, широкого застосуванням нових, нетрадиційних форм навчання. Нині, основним принципом удосконалення системи освіти СШАє підвищення рівня якості підготовки кадрів, зокрема професіоналізму для всіх ланок занятості.

У новому тлумачному словнику української мови професіоналізм трактується як “оволодіння основами і глибинами якої-небудь професії” [3, 62]. 
С.А. Дружилов підкреслює, що професіоналізм - це не тільки досягнення фахівців високих виробничих показників, а й особливості їх професійної мотивації, система прагнення, ціннісних орієнтацій, сенсу праці. На його думку, поняття “професіоналізм” висвітлює такий ступінь оволодіння людиною психологічною структурою професійної діяльності, яка відповідає існуючим в суспільстві стандартам і об'єктивним вимогам держави [1].

Таким чином, можна зазначити, що формування професіоналізму у студентів - це безперервний, систематичний процес, ефективно і правильно виконувати поставлені завдання в опануванні навчальною дисципліною, щоб здобуги такі знання, уміння, навички, які будуть доведені до автоматизму. Їх важливо моделювати у студентів відповідно до стандартів освіти і освітньої політики держави, яка відображає інтереси суспільства, формує суспільний попит на знання і перспективи, розвивається під впливом часових, соціальних, економічних та інших чинників. Важливо формувати у студентів професіоналізм, щоб він відповідав міжнародним вимогам і стандартам. Враховуючи власні досягнення та надбання у діяльності вищих закладів освіти, необхідно вивчати зарубіжний освітній досвід та впроваджувати новітні технології навчання до навчального процесу, особливо ті інновації, які позитивно вплинуть на рівень формування якості професіоналізму студентів, додадуть вагомості українським дипломам, одержаними фахівцями відповідно до вимог загальноосвітніх стандартів.

Формування професіоналізму - це тривалий процес і зазвичай, він починається на ранній стадії розвитку дитини. Ми спостерігаємо за дитиною як вона розвивається, що їй подобається та чим вона захоплюється. Важливо формувати уміння i навички у дитинстві, на початкових курсах вивчення навчальної дисципліни. Наприклад, в опануванні іноземної мови дітям у ранньому віці, не потрібна систематична граматика 3 усіма правилами і винятками, а обдумана система практичної початкової граматики, яка вела б їх прямо до мети без витраченого даремно часу, без пропусків чого-небудь важливого, суттєвого, без зайвих повторів, від простого до складного, від легкого до більш важкого. В цей період діти не отримують лекційної та семінарської інформації. Інша справа 3 навчанням студентів, які мають осмислити завдання і мету навчання, оскільки вони оволодівають не лише знаннями необхідними для подальшої праці, але i формують професіоналізм з обраної професії.
Спостерігаючи за аудиторією, іноді стає прикро, що для одних - нова навчальна дисципліна, нове завдання має смисл, а для других - це чергове тяжке випробування, для третіх - повсякденна неминуча нудна справа, необхідна для отримання диплому про освіту.

Відповідно до цього у студентів формується і проявляється певне ставлення до вивчення навчального предмета, до навчання в цілому, що в результаті так чи інакше проявляється в усій діяльності майбутнього спеціаліста.

Переконання педагога, що всі студенти здібні і можуть перемагати труднощі в навчанні відіграє неабияке значення. Проте, несправедливо і негуманно, коли викладач, не розібравшись у реальних причинах невдач у навчанні студента, виливає на його свій гнів, висловлює необгрунтовані звинувачення. Звичайно, студент не в силі зрозуміти викладача, сприйняти його негативну оцінку, її справедливість. Він скоріше буде намагатися вийти 3 поля педагогічного впливу, ніж тяжіти до нього.

Чимало успіхів у системі вищої освіти досягнуто у США. Завдяки реформам в американському суспільстві освіта дедалі стає більш відкритою та різноманітною. Особливої ваги набуває процес формування професіоналізму студентів, бо програми в американських закладах вищої освіти спрямовані на отримання професії вузької спеціалізації.

Саме відсутність безпосереднього спілкування студентів США, яке відбувається на основі анонімних тестів, ставить потребу іншого характеру: вдосконалювати підходи до навчання; розглядати стосунки між викладачами та студентами в процесі вивчення навчальної дисципліни; глибока повага до особистості; винятково широка можливість вільного висловлення думки без їі прямого осудження, якщо навіть вона неправильна.

Всі ці підходи грунтуються на загальносуспільних політичних засадах США про права і свободи людини. Однак, це зовсім не означає, що зменшується вимогливість з боку викладача до студентів, послаблюється роль здобування знань і формування професіоналізму.

У процесі формування професіоналізму студентів значна увага відводиться виконанню контрольних завдань, тестів, вправ, бо вони складаються відповідно до їхнього рівня знань і вказують на рівень професійності, здобутих умінь i навичок. Завдання щодо формування професіоналізму студентів характеризують: підвищення ролі складання та виконання тестів, письмових робіт, контрольних завдань; здійснення 
процесупедагогічного оцінювання знань студентів зі швидкістю, що відповідає їхнім здібностям у зв'язку з відсутністю чітко не окресленого періоду навчання в університетах; грунтовне оволодіння матеріалом з предмета, що вивчається та можливості перейти до наступного опанування тільки після засвоєння попереднього; використання спеціального персоналу методистів - консультантів, інспекторів для систематичної перевірки знань студентів і оперативного підведення підсумків.

Нині у США приділяють значну увагу новітнім технологіям, умінням користуватися Інтернет ресурсами, виокремлюючи десять важливих умінь які необхідні педагогу в процесі викладання навчального предмета.

Джанелл Кокс (Janelle Cox) зазначає, щоб бути професійним у викладання навчальної дисципліни і здібним формувати професіоналізм у студентів, необхідно урізноманітнити навички викладання, поєднуючи із знаннями і досвідом. Щоб крокувати iз вимогами третього тисячоліття, викладач має оволодіти новими важливих уміннями які необхідні для педагога в процесі викладання навчального предмета, зокрема такими, уміння: терпіти, користуватися новітніми технологіями, креативності, командної гри, управління онлайн технологіями, комунікативності, пошуку необхідних ресурсів в Інтернет мережі, безперервного навчання, відчуття темпу вивчення навчальної дисципліни, адаптації до нових студентів та їхніх здібностей вивчати навчальний предмет [5].

Уміння терпіти. Терпіння викладача, уміння витримати забаганки учнів, а іноді і непристойну поведінку та відповідь студентів, щоб потім порозумітися і знайти спільні підходи до опанування навчальної дисципліни. Завдяки терпінню викладача, його вмінню чекати, студентів не охоплюють зайві емоції і він не поспішає робити вчинків у роздратуванні. Якщо $є$ терпіння у педагога, тоді він здатний бачити, але не помічати, чути, але не дослуховуватися. Такий педагог може багато що чути, але слухати лише те, що обиратиме сам. Мудрість терпіти саме полягає в тому, щоб бачити, але не дивитись, чути, але не слухати. Якщо викладач оволодіє цією мудрістю, яка приходить завдяки терпінню, тоді він автоматично здатний використовувати свій інтелект, як фільтр, який всередині лишає тільки необхідне, а все непотрібне очищає.

Уміння користуватися новітніми технологіями - це необхідність сучасного викладання навчальної дисципліни, - це вимога нового тисячоліття, щоб крокувати в ногу з новими технологіями. Викладач не лише повинен уміти користуватися сучасними технологіями, але і знати який цифровий прилад підходить для студентів. Новітні технології допомагають студентам краще розвивати власні пізнавальні здібності, збагачувати власний досвід, допомагати пізнати себе, самовизначитися та самореалізуватися, сформувати професіоналізм, що необхідний для подальшого працевлаштування.

Креативність - це постійний пошук оригінальних вирішень поставлених завдань, творчість мислення і фантазія, здатність бачити послідовність дій і прикінцевий результат. Джанелл Кокс (Janelle Cox) зазначає, що найефективнішим інструментом, який педагог повинен використовувати - це його уява. Оскільки загальні державні стандарти США (Common Core State Standards (CCSS) впроваджуються у навчальних закладах, тому викладачі вважають, що їм потрібно використовувати свою уяву більше, ніж будь-коли. Саме тому, педагоги повинні використовувати творчість у навчальному процесі і придумувати унікальні способи зацікавити студентів у вивченні навчальної дисципліни [4].

Командна гра полягає в тому, щоб викладач працював у команді і був їі частиною. Джанелл Кокс (Janelle Cox) називає це “командним навчанням", коли педагог виконую завдання разом із студентами, тоді це надає вихованцям краще опанувати знання і здобути професійні навички для своєї професійної зайнятості. Оскільки командна гра - випробування, витримка, активність і підготовка до корисної праці, тому важливо впроваджувати ігрові моменти в процесі вивчення навчальної дисципліни.

У процесі командної гри студенти зосереджуються і прагнуть швидше виконати завдання за іншу команду, таким чином розвивається увага і творчість мислення, і вони не помічають, що навчаються під керівництвом викладача. Як правило, командні ігри 3 елементами змагання відбуваються із задоволенням і без примусу. Якщо такі заняття iз командної гри проходять у системі вивчення навчальної дисципліни, тоді цей вид роботи приносить відчутні результати в розвитку професіоналізму студентів.

Уміння управляти он-лайн технологіями. Із розвитком сучасних технологій більшість викладачів $€$ в он-лайн. Сучасні викладачі повинні знати, як управляти своєю онлайн технологіями, оскільки дії в інтернет мережі здійснюються в режимі реального часу.

Розвиток он-лайн технологій, зокрема інформаційних сприяє розвитку інтелектуальних здібностей студентів вивчати навчальну 
дисципліну, прогнозування результатів своєї діяльності, розробляти стратегію пошуку шляхів і методів вирішення завдань - як навчальних, так і практичних.

Уміння управляти он-лайн технологіями забезпечує швидкий зворотний зв'язок між викладачем і студентами, i безумовно, вчасного i успішного виконання завдань із навчальної дисципліни.

Комунікативність. Вміння викладача спілкуватися зі студентами, колегами, викладачами, батьками - це майстерність педагога вести розмову і підтримувати діалог в процесі співбесіди.

В. Кан-Калик виділяє найбільш дієві вміння комунікації, зокрема вести бесіду із студентами через правильно створену систему спілкування, організовувати спільну з учнями творчу діяльність, вміння цілеспрямовано організовувати спілкування й керувати ним $[2,46]$. Педагог може здійснювати комунікаційний зв'язок, лише при наявності певних комунікативних здібностей, зокрема емоцій, бажанням ділитися думками, переживаннями, почуттям симпатії та антипатії, поваги до студентів і спілкування з ними т. ін. Саме наявність цих емоцій і потреби в їх здійсненні засвідчують про схильність викладача до комунікації, його готовність вести співбесіду на теми вивчення навчальної дисципліни.

Пошук необхідних ресурсів в Інтернет мережі засвідчує здібності викладача користуватися Інтернет ресурсами, зокрема вміння знаходити творчі та привабливі ресурси, які допоможуть зацікавити студентів в опануванні навчальною дисципліною; пошук нових додатків для використання і перегляду веб-сторінок для грунтовного вивчення навчальної дисципліни та вдосконалення навичок професійної діяльності. Мережа Інтернет відкриває широкі можливості використання освітніх Інтернет ресурсів в роботі педагога, зокрема це доступ до ресурсів як до інструменту пошуку необхідного додаткового матеріалу у вивченні навчальної дисципліни, вдосконалення спілкування та інтелектуального досвіду, забезпечення існуючим світом досвідом і т.д.

Безперервне навчання передбачає для педагогів підвищення кваліфікації, бо вони усвідомлюють, що потрібно постійно шукати істину і не можна навчитись занадто багато, тому викладачі намагаються відвідувати семінари, майстер класи, проходити курси підвищення кваліфікації, що зробить їх кращими у процесі викладання навчальної дисципліни. Слід зауважити, що в інформаційному суспільстві існує багато факторів, які обумовлюють необхідність постійного оновлення отриманої освіти, щоб вчасно представити сучасний матеріал для опанування навчальною дисципліною.

Відчуття темпу вивчення навчальної дисципліни, викладачі темп вивченні навчальної дисципліни, зокрема готовність студентів до визначення рівня якості знань. Якщо програму опанування навчальним матеріалом вичерпано, тоді відводиться час на повторення, тому педагоги уповільнюють темп подачі нового матеріалу.

Адаптація до нових студентів та їхніх здібностей вивчати навчальну дисиипліну, ці вміння повинен мати кожен викладач, бо йому необхідно адаптуватися до того як студенти швидко опановують навчальну дисципліну i вивчають новий матеріал; до поведінки студентів їх вимог; планами уроків тощо.

У процесі вивчення навчального матеріалу і опанування навчальною дисципліною, педагоги США тактовно нагадують своїм студентам, що отримання змістовних знань в опануванні навчального предмета та здобуття професійних навичок необхідні для працевлаштування майбутніх спеціалістів, бо вищі американські заклади освіти не гарантують своїм випускникам забезпечити їх роботою. Для опанування змістовними знаннями 3 навчального предмета студентам США пропонують обов'язкові навчальні програми та вибір додаткових курсів для поглибленого вивчення навчального предмета і здобути навички професіоналізму. Кращі вищі заклади освіти США надають своїм студентам можливості прослухати курси, які відповідають їхнім індивідуальним потребам і яких немає в плані університету, але здобуті знання, уміння, навички необхідні для подальшого працевлаштування. Саме тому в США існує домовленість між університетами відносно того, щоб направляти своїх студентів $з$ одного вищого закладу освіти до іншого з метою прослухати додаткові курси, якими зацікавились студенти i на яких вони підвищать рівень якості свого професіоналізму. Такий обмін студентів значно впливає на отримання грунтовних знань у вивченні навчального предмета, та опанування відповідними уміннями і навичками щодо формування професіоналізму для майбутнього працевлаштування.

Міжвузівська організація навчання в США $є$ однією 3 найбільш цікавих, яка приваблює європейських експертів. Головною і1ї привабливістю $-\epsilon$ мобільність. Крім основних теоретичних дисциплін, що є фундаментом 
навчання, до програми навчання включають порівнюючи короткі спеціалізовані курси, які можна оперативно вдосконалити з урахуванням нових досягнень науки й техніки, а також при необхідності можна легко розробити нові міжпредметні курси для організації підготовки спеціалістів за новими напрямами, які диктує науково-технічний прогрес.

Міжвузівська організація навчання в США має позитивні результати в процесі оцінювання знань студентів, зокрема майбутніх лікарів. Майбутні спеціалісти оволодіють необхідними знаннями, уміннями, навичками, які вимагає сучасна освіта, а вищі навчальні заклади легко пристосовуються до нових вимог розвитку науки й техніки.

Творчі пошуки спеціалістів особливо відчутні в країнах, які зуміли досягти високого економічного розвитку, здійснити перетворення в житті свого народу, держави.

У вищих навчальних закладах України існує ще багато проблем. На практиці нерідкі випадки пропусків занять студентами, користування шпаргалками та списування під час іспитів, нездатність студентів до критичного мислення та недостатність ініціативи у навчанні, зокрема у формуванні власної свідомості та професіоналізму.

Висновки. Слідуючи принципу історизму, ми коротко проаналізували факти, які були поштовхом до формування професіоналізму студентів США, зокрема майбутніх лікарів. В історичному розгляді вища освіта США характеризується певними особливостями, а саме тим, що типом вищої освіти США стала загальна вища освіта, яка мала довгий шлях формування.

Важливо побудувати сучасну освіту в контексті вимог і можливостей, що відповідають міжнародним стандартам і відрізняються рівнем якості знань, умінь, навичок та підходами до процесу опанування навчальними дисциплінами, до формування професіоналізму фахівців, зокрема майбутніх лікарів. Для успішного розв'язання проблеми формування професіоналізму студентів вищих закладів освіти в Україні необхідно вивчати зарубіжну практику та впроваджувати кращий досвід до навчального процесу.

Однак не варто вдаватись до запозичення i копіювання зарубіжного досвіду. Необхідно переконатися у можливості адаптації цього досвіду до загальнокультурних, соціальноекономічних та інституційних умов України, здійснити діагностику переваг та недоліків його впровадження, а також враховувати традиції та досягнення у діяльності вітчизняних вищих закладів освіти, що відповідають сучасним векторам розвитку освіти у світі.

Модернізація нових форм і методів навчання, зокрема підходів до формування професіоналізму студентів $є$ важливим засобом підвищення рівня якості освіти. Проаналізовані підходи до формування професіоналізму студентів, зокрема лікарів США можна використати для формування професіоналізму студентів у вищих закладах освіти України. Професіоналізм студентів як України, так і США включає певні якості особистості: уміння самостійно здобувати знання; удосконалювати уміння і навички і доводити їх до автоматизму; уміння креативно і критично мислити та опрацьовувати великий обсяг інформації; комунікативність; уміння користуватись новітніми технологіями навчання.

\section{ЛІТЕРАТУРА}

1. Дружилов С. А. Концептуальная модель профессиональной деятельности как психологическая детерминанта профессионализма. Психологические исследования. 2013. Т. 6. № 19.

2. Кан-Калик В. А. Учителю о педагогическом общении: Кн. для учителя. Москва, 1987. С.4662.

3. Новий тлумачний словник української мови у 3 Т. Київ. 2007.

4. Регульовані професії: взаємодія держави, роботодавців, закладів освіти та професійних спільнот для досягнення кращих результатів обговоримо проект MOH. URL: http:// www.osvita.org.ua/news/80249.html

5. Cox Janell 10 Useful Skills Modern Teachers Need. [Electronic resource]. Available at: https:// www.thoughtco.com/useful-skills-modern-teachersneed-2081527

6. The International Foundation of Medicine (IFOM). [Electronic resource]. Available at: https:// www.nbme.org/ifom/

\section{REFERENCES}

1. Druzhilov, S. A. (2013). Kontseptualnaya model professionalnoy deyatelnosti kak psikhologicheskaya determinanta professionalizma [The conceptual model of professional activity as a psychological determinant of professionalism]. Psychological research. Vol. 6. No. 19. [in Russian].

2. Kan-Kalik, V. A. (1987). Uchitelyu o pedagogicheskom obshchenii: Kn. dlya uchitelya [For the teacher about pedagogical communication: Book for teachers]. Moscov, pp.46-62. [in Russian].

3. Novyi tlumachnyi slovnyk ukrainskoi movy u $3 T$ [New explanatory dictionary of the Ukrainian 
language in 3 volumes]. Kyiv. 2007. [in Ukrainian].

4. Rehulovani profesii: vzaiemodiia derzhavy, robotodavtsiv, zakladiv osvity ta profesiinykh spilnot dlia dosiahnennia krashchykh rezultativ- obhovorymo proekt MON [The regulated professions: the interaction of the state, employers, educational institutions and professional communities to achieve the better results - we will discuss the project of the
Ministry of Education and Science]. [Electronic resource]. Available at: http://www.osvita.org.ua/ news/80249.html [in Ukrainian].

5. Cox Janell 10 Useful Skills Modern Teachers Need. [Electronic resource]. Available at: https://www.thoughtco.com/ useful-skills-modern-teachers-need-2081527 [in English].

6. The International Foundation of Medicine (IFOM). [Electronic resource]. Available at: https:// www.nbme.org/ifom/ [in English].

Стаття надійшла до редакції 19.06.2019

УДК 378.145.026:81.111

DOI:

Наталія Жорняк, кандидат педагогічних наук, доцент, доцент кафедри іноземних мов Національного університету “Львівська політехніка"

\section{МІЖНАРОДНИЙ ДОСВІД ОСВІТНІХ ПРОГРАМ ДЛЯ КОРІННИХ НАРОДІВ}

У статті розглянуто міжнародний досвід створення умов та впровадження програм для покращення якості освіти корінних народів, подано характеристику ключових історичних етапів розвитку освіти корінних народів, дано визначення самому поняттю “корінні народи”. Детально вивчено основні напрямки та вжиті стосовно них заходи для забезпечення корінних жителів якісними освітніми можливостями. Особливу увагу приділено аналізу дипломних програм та освітніх проектів Канади та Австралії.

Ключові слова: освітня діяльність; корінне населення; спільнота; культурні відмінності; культурна відповідність; навчальний центр.

Jim. 16.

Nataliya Zhornyak, Ph.D.(Pedagogy), Associate Professor of the Foreign Languages Department, Lviv Polytechnic National University

\section{INTERNATIONAL PRACTICE OF IMPLEMENTING EDUCATIONAL PROGRAMS FOR INDIGENOUS PEOPLE}

The article deals with the international experience of creating conditions and implementing programs for improving the quality of education of indigenous peoples, the key historical stages of development of indigenous peoples' education are described; the concept "indigenous peoples" is defined. Among the main obstacles encountered on the way to the education of indigenous peoples, the historical social, geographical, demographic, cultural and individual ones were highlighted. The main directions and measures taken to provide indigenous peoples with high-quality educational opportunities are studied in detail. Particular attention is paid to the analysis of diploma programs and educational projects in Canada and Australia. Over the past decades, indigenous education has undergone radical changes and has begun to respond to the philosophy and needs of indigenous people. Canada's history of indigenous education identifies four historical stages: the traditional, the period of industrial boarding schools run by the federal government, provincial school education, and the era of Indian control over Indian education. The history of the education of Australian Aborigines is traditionally divided into three stages - the missionary, protectionist, and assimilation; the latter, now being somehow smoothed by the cultural relevance approaches and attempts to meet the needs of communities. It is worth noting that indigenous peoples' involvement in educational programs takes place both explicitly and implicitly. On the one hand, higher educational establishments and schools create special conditions for admittance and learning for Aborigines. On the other hand, with the help of individual courses or modules, they acquaint others with the culture, customs and life of these peoples.

Keywords: educational activity; indigenous population; community; cultural differences; cultural correspondence; an educational center.

П остановка проблеми. Щоденна взаємодія з людьми, яким притаманні неоднакові цінності, соціальні звичаї та способи сприйняття реальності, стала безумовною нормою, а не винятком. Ера цифрових технологій та поглиблення глобалізаційних процесів в рази пришвидшили цю співдію та зумовили зростання культурної різноманітності населення та робочої сили. Тому здатність працювати у мультикультурному середовищі стає 